\title{
有機シリルおよび有機ゲルミルアミンと $\beta$-プロピオラクトンとの反応の速度論的研究*1,*2
}

\author{
(昭 和 41 年 9 月 22 日受理)
}

伊藤 健 巟・加藤陽之輔・酒井鎮美・石井義郎*3

トリメチルシリルおよびトリアルキルゲルミルジフルキルフミンによる $\beta$-プロピオラクトン $(\beta-\mathrm{PL})$ の開環反応の速度論的研 宛を， $\beta$-PL の減少量を赤外吸収スペクトルで追求して行なった。両有機金属アミンの反応とも二次速度式が適用でき，また反応 速度は母体第二アミンから推定される有機金属了ミンの塩基性の增大とともに，かつ溶媒の極性の增加とともに大きくなる。トリ メチルゲルミル体の反応性はトリメチルシリル体のそれよりる約 10 倍大きい。例えばェチレンシクロリド中 $65^{\circ} \mathrm{C}$ の $k_{2}\left(l / \mathrm{mol}^{\circ}\right.$ sec) は $\left(\mathrm{CH}_{3}\right)_{3} \mathrm{Si}-\mathrm{N}\left(\mathrm{C}_{2} \mathrm{H}_{5}\right)_{2}$ で $6.10 \times 10^{-4}$ ， た $\left(\mathrm{CH}_{3}\right)_{3} \mathrm{Ge}-\mathrm{N}\left(\mathrm{C}_{2} \mathrm{H}_{5}\right)_{2}$ で $5.71 \times 10^{-3}$ である。

\section{1 緒言}

第 $\mathrm{N}$ 族金属原子と窒素原子の結合を有する化合物 $(>\mathrm{M}-\mathrm{N}<)$ は対応する脂肪族アミンにくらべて特異な反応を行なう。たと文 ば不飽和結合化合物 ( $\mathrm{A}=\mathrm{B})$ に対する付加反応が可能であること が最近明らかにされた。この反応は一般式（1).で示され， $\mathrm{M=}$ $\mathrm{Si}^{1)}, \mathrm{Ge}^{2)}, \mathrm{Sn}^{3)}$ および $\mathrm{Pb}^{4)}$ について報告されている。

$$
>\mathrm{M}-\mathrm{N}<+\mathrm{A}=\mathrm{B} \rightleftarrows>\mathrm{M}-\mathrm{A}-\mathrm{B}-\mathrm{N}<
$$

付加反応の別の形式として環歪を有する環状化合物に対する開 環付加反応が考えられるが，現在まで著者らの研究5 7) 以外には 報告がない。著者らは $\beta$-プロピオラクトン $(\beta-\mathrm{PL})$ が有機シリ ルー6)，有機ゲルミル-6)および有機スタニルジアルキルアミンどに より開環反応を受けることを見出し，その開環の方向性を明らか にした。すなわち $\mathrm{M}=\mathrm{Si}$ および $\mathrm{Ge}$ ておいては, $\beta-\mathrm{PL}$ のアル

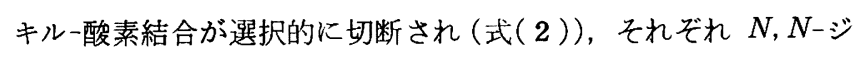

*1 この報文を「第 IV 族有機金属化合物の反忍（第 4 報）」 とする。

*2 前報 (第 3 報), K. Itoh, S. Sakai, Y. Ishii, J. Org. Chem., 印刷中, “The Reaction of Trimethylsilyldialkylamines with Epoxide".

*3 Kenji ITOH, Yonosuke KATO,. Shizuyoshi SAKAI, Yoshio Ishii 名古屋大学工学部合成化学科：名古屋市千 種区不老町.

1) a) H. Breederveld, Rec. Trav.Chim., 79, 1126 (1960); 81, 276 (1962) ; b) G. Oertel, H. Mälz, H. Holmschmidt, Chem.Ber., 97, 891 (1964) ; c) W. Fink, ibid., 97, 1433(1964) ; d) J. F. Klebe, J. B. Bush, J. E. Lyons, J. Am. Chem. Soc., 80, 4400 (1964) ; e) A. G. Davies, 石井義郎, 日本化学会 18 年会要旨集, p. 436, 大阪 (1965).

2) J. Satgé, M. Lesbre, M. Baudet, Compt. Rend., 259 , 4733 (1964).

3) T. A. George, K. Jones, M. F. Lappert, J. Chem. Soc., 2157 (1965).

4) W. P. Neumann, K. Kühlein, Tetrahedron Letters, 3423 (1966).

5) K. Itoh, S. Sakai, Y. Ishii, J. Org. Chem., 31, 3948 (1966). "The Reaction of Trimethylsilyldialkylamine with $\beta$-Propiolactone".

6) K. Itoh, S. Sakai, Y.Ishii, Tetrahedron Letters, 4691 (1966). "Dual Behavior of the Ring Opening of $\beta$ Propiolactone by Trimethylsilyl-, Germyl- and Stannylamines".

7) K. Itoh, S. Sakai, Y. Ishii, J. Org. Chem., 印刷中, "The Reaction of Trimethylsilyldialkylamines with Epoxides".
アルキルー $\beta$ アラニントリメチルシリルおよびトリアルキルゲル ミルエステル（Ｉ）を生成するが, $\mathrm{M}=\mathrm{Sn}$ の場合はアシル-酸素

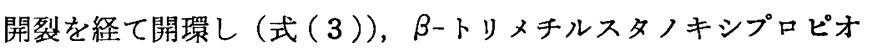
ン酸- $N, N$-ジアルキルアミド (II) を生成する。

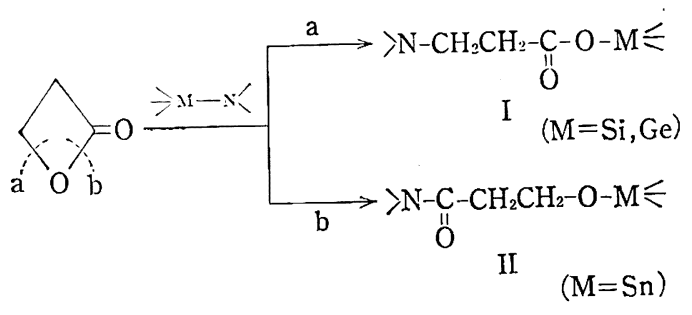

$\mathrm{a} ：$ アルルー酸素開裂， b: ア アシルー酸素開裂

一般に有機金属化合物の反応性はきわめて大きいので速度論的 研究を行な5ことは困難である。第 $\mathrm{N}$ 族金属-窒素結合を有する 化合物と不飽和化合物の付加反応の速度論的研究も同じ理由で行 なわれていない。

しかしながら $\mathrm{Me}_{3} \mathrm{Si}-\mathrm{X}$ (X としてジェチルアミノ基, $N$-ピペ リジル基抽び $N$-ピロリジル基) また $\mathrm{Me}_{3} \mathrm{GeX}-(\mathrm{X}$ としてジェ チルアミノ基および $N$-ピペリジル基), $n-\mathrm{Bu}_{3} \mathrm{Ge}-\mathrm{NEt}_{2}$ による $\beta-P L$ の開環反応は $50 \sim 75^{\circ} \mathrm{C}$ において反応試薬である $\beta$-PL の 减少量を赤外吸収スペクトルで追求できるので速度論的研究が可 能である。

本報はトリアルキルシリルアミンおよびトリアルキルゲルミル アミンによる $\beta$-PL の開環反応速度に対する有機金属アミンの種 類の影響, 溶媒の効果などについて検討し反応機構を推定した結 果である。

\section{2 実験}

\section{$2 \cdot 1$ 試 料}

トリメチルシリルジアルキルアミンは第 1 報可の方法にしたが って $\left(\mathrm{CH}_{3}\right)_{3} \mathrm{SiCl}$ から合成した。またトリメチルおよびトリーnー ブチルゲルミルジァルキルアミンはそれぞれ $\left(\mathrm{CH}_{3}\right)_{3} \mathrm{GeI}$ および $\left(n-\mathrm{C}_{4} \mathrm{H}_{9}\right)_{3} \mathrm{GeCl}$ から Satge らの方法2) で合成し, 蒸留により精 製して使用した。ß-PL はダイセル社製品を $30 \mathrm{~cm}$ ウィドマー精 留塔を用いて精留を二度行ない, bp $64.0 \sim 64.5^{\circ} \mathrm{C} / 25 \mathrm{mmHg}$ の 留分を使用した。エチレンジクロリドなどの溶某はすべて市販の 試薬 1 級品を常法により精製し, $\mathrm{CaH}_{2}$ で乾燥後精留し使用した。 $2 \cdot 2$ 操 作

アルゴン置換した $10 \mathrm{ml}$ メスフラスコに $1.00 \mathrm{~m} \mathrm{~mol}$ の有機 金属アミンを秤り取り, 溶媒で $10 \mathrm{ml}$ に希釈する。所定温度に 
保った $\left( \pm 0.10^{\circ} \mathrm{C}\right)$ 恒温槽に電磁式かさまぜ機およびシリコンゴ ムで止めたジムロート冷却器(長さ $20 \mathrm{~cm}$ )を付しアルゴン置換し た $20 \mathrm{ml}$ の三角フラスコを設置する。この三角フラスコ内に上 記有機金属アミン溶液を移しマイクロシリンジで $1.00 \mathrm{~m} \mathrm{~mol}$ の $\beta-P L$ を加えて反応を開始させる。所定時間ごとに乾燥した $1 \mathrm{~m} l$ 注射器を使用してシリコンゴムを通して試料溶液をぬき出し, $0.05 \mathrm{~mm}$ セルに移して $\beta$-PL に特徵的な $\nu_{\mathrm{C}=0} 1833 \mathrm{~cm}^{-1}$ の吸 収強度を測定することにより, 残存する $\beta-P L$ の濃度を決定し た。赤外吸収スペクトルの測定には日本分光 IR-S 型分光訃を用 いた。

\section{3 結果および考察}

\section{$3 \cdot 1$ トリメチルシリルジアルキルアミンと $\beta$-PL の反応}

\section{$3 \cdot 1 \cdot 1$ 反応速度におよぼす有機金属アミンの塩基性の影響}

トリメチルシリルジアルキルアミンは $\beta-P L$ と反応し, 式 (2) にしたがって $N, N$-ジアルキルー $\beta$-アラニントリメチルシリルエ ステルを生成することはすでに報告しだ)。本節の速度論的研究

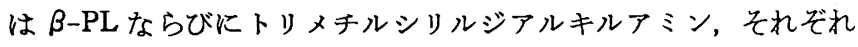
$0.100 \mathrm{~mol} / l$ の初濃度を用い, エチレンジクロリドを溶媒として 行なった。赤外吸収スペクトルにより $\beta-P L$ に特徵的な $\nu_{\mathrm{C}=0}$ $1833 \mathrm{~cm}^{-1}$ の強度测定から $\beta-\mathrm{PL}$ の濃度を求め, 綐軸に $1 /[\beta-$ PL] を, 横軸に反応時間をとり, 二次速度式に従うとしてプロッ トしたところ直線関係が成立した。すなわちこの反応は二次式に したがうことが明らかになった。また $\mathrm{Me}_{3} \mathrm{Si}_{-} \mathrm{NEt}_{2}$ を $0.100 \mathrm{~mol} / l$ とし， $\beta$-PL $0.100,0.140$ および 0.170 と変化させ, $72.0^{\circ} \mathrm{C}$ ーエチレンジクロリド中で速度を上と同様に測定したところ, 全 て二次式に適合することが明らかになった。なおこの測定の時間変化率曲線の $t=0$ における傾斜の対数を縦軸に, $\log [\beta-\mathrm{PL}]$ を 横軸にプロットすると良好な直線関係が得られ, その傾斜は 0.98 であった。すなわち速度は $\beta$-PL の一次に依存することがわかり 先の結果と合わせて， $\beta-P L$ および有機金属アミンそれぞれの一 次に従 5 結論できる。

速度論的研究の濃度において反応率を $30 \%$ 以下にし，その後 減圧下に $\beta-\mathrm{PL}$ ，エチレンジクロリドおよび $\mathrm{Me}_{3} \mathrm{Si}_{-} \mathrm{NEt}_{2}$ を除去 した残分の赤外吸収スペクトルは先に構造を決めた ${ }^{5)} N, N$-ジェ チルー $\beta$ アラニントリメチルシリルと同一であり, また反応進行 とともにすべてのトリメチルシリルアミンについてトリメチルシ リルエステルに特有な $\nu_{\mathrm{C}=0}$ が $1718 \sim 1723 \mathrm{~cm}^{-1}$ に增大してくる ことは, この濃度で $\beta$-PL がアルキル-酸素開裂をしてくること を示す。もし、アシルー酸素開裂が起こる（式（３）II）ならば第三 アミドの $\nu_{\mathrm{C}=0}$ を示すはずである。事実, 別途から合成した ${ }^{16)} \beta-$ オキシプロピオン酸ジェチルアミドは $1622 \mathrm{~cm}^{-1}$ にきわめて強い $\nu_{\mathrm{C}=0}$ を有する。しかるに本実験では $1600 \sim 1700 \mathrm{~cm}^{-1}$ には吸収 はまったく存在せず, 反応進行とともにこの領域には何の吸収も あらわれないのでアシルー酸素開裂はおこっておらず，反応は選 択的にアルキルー酸素開裂をともなって進行しているものと考え られる。

$N$-トリメチルシリルピロリジン,$N$-トリメチルシリルピペリ ジンおよびトリメチルシリルジェチルアミンについて， $62 \sim 75^{\circ} \mathrm{C}$ の間の 4 つの温度で測定して得た二次速度定数 $k_{2}(l / \mathrm{mol} \cdot \mathrm{sec})$ お よびそれらから得た活性化パラメータを表 1 に示した。

同一温度に抽 $k_{2}$ を比較して明らかなように，ヶイ素と結
表 1 エチレンジクロリド中に拈るトリメチルシリルジァ ルキルアミンと $\beta$-プロピオラクトンとの二次速度定数

$\left([\beta-\mathrm{PL}]_{0}=\left[\left(\mathrm{CH}_{3}\right)_{3} \mathrm{SiNR}_{2}\right]_{0}=0.100 \mathrm{~mol} / l\right)$

\begin{tabular}{|c|c|c|c|c|}
\hline $\begin{array}{l}\text { トリメチルシリル } \\
\text { ジアルキルアミン }\end{array}$ & 温 $(C)^{1 / 3}$ & $\left(\begin{array}{c}k_{2} \\
\left(l / \mathrm{mol}^{\prime} \cdot \mathrm{sec}\right)\end{array}\right.$ & $\begin{array}{c}E_{\mathrm{a}} \\
(\mathrm{kcal} / \\
\mathrm{mol})\end{array}$ & $\begin{array}{c}\Delta S^{*} \\
(\mathrm{cal} / \mathrm{deg} \\
\cdot \mathrm{mol})\end{array}$ \\
\hline$\left(\mathrm{CH}_{3}\right)_{3} \mathrm{Si}-$ & $\begin{array}{l}65.0 \\
70.0 \\
72.0 \\
75.0\end{array}$ & $\begin{array}{l}(6.10 \pm 0.04 *) \times 10^{-4} \\
(9.13 \pm 0.03) \times 10^{-4} \\
(1.09 \pm 0.04) \times 10^{-3} \\
(1.48 \pm 0.04) \times 10^{-3}\end{array}$ & 20 & -11 \\
\hline$\left(\mathrm{CH}_{3}\right)_{3} \mathrm{Si}-\mathbf{N}$ & $\begin{array}{l}65.0 \\
67.0 \\
70.0 \\
72.0\end{array}$ & $\begin{array}{l}(3.47 \pm 0.07) \times 10^{-3} \\
(3.87 \pm 0.03) \times 10^{-3} \\
(4.63 \pm 0.06) \times 10^{-3} \\
(5.28 \pm 0.06) \times 10^{-3}\end{array}$ & 13 & -31 \\
\hline 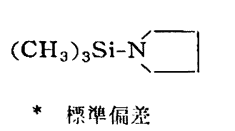 & $\begin{array}{l}62.0 \\
65.0 \\
70.0 \\
73.0\end{array}$ & $\begin{array}{l}(3.85 \pm 0.09) \times 10^{-3} \\
(5.43 \pm 0.08) \times 10^{-3} \\
(8.53 \pm 0.18) \times 10^{-3} \\
(1.10 \pm 0.20) \times 10^{-2}\end{array}$ & 22 & -2 \\
\hline
\end{tabular}

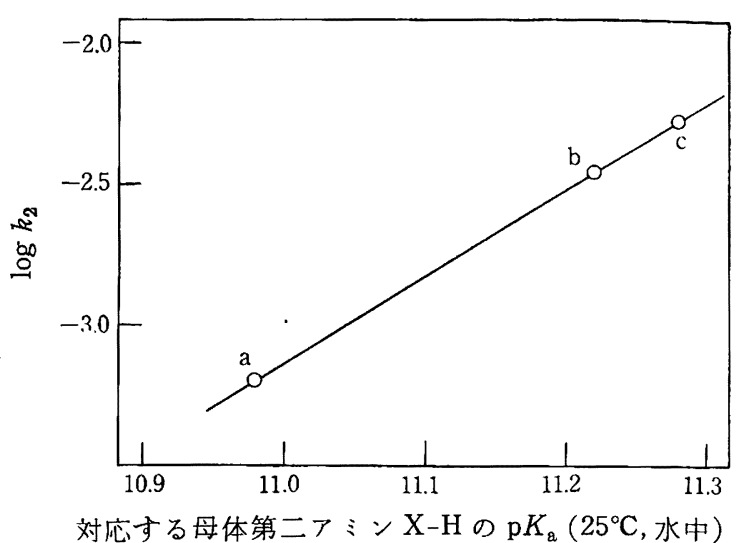

図 1 反応速度に対するトリメチルシリルジフルキルフ ミン, $\left(\mathrm{CH}_{3}\right)_{3} \mathrm{Si}-\mathrm{X}$ の塩基性の影響

(エチレンクロリド中, $65.0^{\circ} \mathrm{C}$ )

$\left.a: X=N\left(C_{2} \mathrm{H}_{5}\right)_{2}, \quad b: \mathbb{N}\right\rangle, c: N$

合している窒素の塩基性の大きなものほど反応性が増大している ことがわかる。すなわち $N$-ピロリジル基 $>N$-ピペリジル基>ジ エチルアミノ基の反応性の順序となっている。窒素原子の塩基性 の尺度として $25^{\circ} \mathrm{C}$-水中に拈ける対応する母体第二アミンの $\mathrm{p} K_{\mathrm{a}}$ 值8) (ピロリジン: 11.27 , ピペリジン: 11.22 およびジェチルア ミン：10.98）を横軸にとり， $65^{\circ} \mathrm{C}$ における反応速度定数の対数 を縦軸にしてプロットすると，図1に示したよ5に良好な直線関 係が成立した。この直線の勾配が 3.2 と大きな值を示すことか ら, 速度決定段階においてトリメチルシリルジアルキルアミンの 窒素原子の塩基性がきわめて重要な役割を演じており，また式 (2)にしたがって $\beta$-PL はアルキルー酸素開裂を経て開環するこ と占と考允合わせて，トリメチルシリルジアルキルアミンの窒素 原子の $\beta$-PL の $\beta$ 炭素原子に対する求核攻撃が，とくに重要で あることがわかる。種々の求核試薬により $\beta$-PL が開環する反応 の二次速度定数 ${ }^{9)}$ の対数は, 求核度定数 $(n)$ と良好な直線関係 を示す事実 ${ }^{10)}$ と考只合わせると，トリメチルシリルジアルキルア ミンは， $\beta$-PL に対し求核試薬として働くと推定できる。

また $N$-トリメチルシリルピロリジンとトリメチルシリルジェ チルアミンにおいては活性化エネルギーがほとんど等しいにもか かわらず, 活性化ェントロピーは後者の方が小さいこと, また窒 素原子の攻揧に対し 1 および 3 位の水素原子による障憲の予想さ

8）湯川泰秀編, “大有機化学別巻 2 ”, 朝倉書店 (1963) p. 584 .

9) P. D. Bartlett, G. Small, Jr., J. Am. Chem. Soc., 72, 4867 (1950).

10) C. G. Swain, C. B. Scott, ibid., 75, 141 (1953), 
れる $N$-トリイチルシリルピベリジンでは，異常に小さな活性化 エントロピーが観察されたことは, トリメチルシリルジァルキル アミンの立休効果がかなり影響していることを示している。また 後述の有機ゲルミルアミンの場合に比して，活性化エネルギー拉 ょび活性化エントロピーともに大きな値を示した。

$3 \cdot 1 \cdot 2$ 反㤁溶媒の影響 4 種の溶媒について, 3.1.1 で記し たと同溙に $\beta$-PL と $N$-トリメチルシリルピペリジンの反応に対 し測定した結果を表 2 に示す。

表 $2 N-$ トリメチルシリルピペリジンによる $\beta$-プロピ オラクトンの開環反応速度に対する溶媒の影響 $\left([\beta-\mathrm{PL}]_{0}=\left[\left(\mathrm{CH}_{3}\right)_{3} \mathrm{SiNC}_{5} \mathrm{H}_{10}\right]_{0}=0.100 \mathrm{~mol} / l, 70^{\circ} \mathrm{C}\right)$

\begin{tabular}{lcc} 
溶 & $\begin{array}{c}k_{2} \\
(1 / \mathrm{mol} \cdot \mathrm{sec})\end{array}$ & $(\varepsilon-1 / 2 \varepsilon+1) 25^{\circ} \mathrm{C}^{*}$ \\
\hline トルェン & $4.57 \times 10^{-4}$ & $2.40 \times 10^{-1}$ \\
フルオルベンゼン & $1.57 \times 10^{-3}$ & $3.73 \times 10^{-1}$ \\
o-ジクロルベンゼン & $2.18 \times 10^{-3}$ & $4.28 \times 10^{-1}$ \\
エチレンジクロリド & $4.63 \times 10^{-3}$ & $4.75 \times 10^{-1}$ \\
$*$ * 值は文献11)によった。 & &
\end{tabular}

な打反応溶媒が開環様式を変化させないことはトルエンとエチ レンジクロリドの両場合について反応を行ない，生成物が同一で あることから確認できる。両場合について後者の速度定数は前者 のそれに比して約 10 倍も大きいことが明らかとなった。表 2 の 結果をKirkwood 指数に対しプロットした結果を図 2 に示す。 この指数は遷移状態で双極型の電荷分布を示す反応について適用 されることが知られている12)。図2で注注直線関係が成立した事 実から $3 \cdot 1 \cdot 1$ で明らかにした有機シリルアミンの窒素原子の $\beta$ 炭素原子への求核攻撃に打いては, 双極型の遷移状態を経過する ものと推定される。

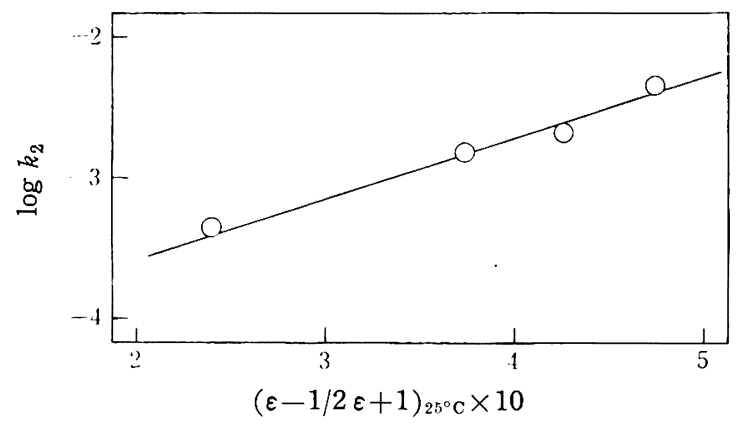

図 2 N-トリメチルシリルピペリジンと $\beta$-プロピオラ クトンとの反応に括ける溶媒の影響 $\left(70.0^{\circ} \mathrm{C}\right)$

\section{$3 \cdot 2$ トリメチルーおよびトリーn-ブチルゲルミルジアルキルア} ミンと $\boldsymbol{\beta}$-PL との反応

エチレンジクロリドおよびトルェンを溶媒として3.1で記した と同樣の方法で, トリアルキルダルミルジアルキルアミンによる $\beta-\mathrm{PL}$ の開環反応の速度論的研究を行なった。この場合の反応生 成物は $N, N$-ジアルキルー $\beta$-アラニントリアルキルゲルミルであ ること（式（2））はすでに報告した6)。また速度諭の浱度範囲に おいては三者についてトリアルキルゲルミルエステルに特徽的な $\nu_{\mathrm{C}=0} 1680 \sim 1690 \mathrm{~cm}^{-1}$ の吸収が反応進行とともに增大してくるこ と拉よびアミドの吸収は $1670 \mathrm{~cm}^{-1}$ 以下に見られないことからも

11) J. A. Riddick, E. E. Toops, Jr., "Organic Solvents", Interscience Pub. Inc., (1955).

12) J. Powling, H. J. Bernstein, J. Am. Chem. Soc., 73, 1815 (1951).
表 3 トリアルキルゲルミルジアルキルフミンと $\beta$ ープ ロピオラクトンの二次反応速度定数

$\left([\beta-\mathrm{PL}]_{0}=\left[\mathrm{R}_{3}{ }^{1} \mathrm{Ge}-\mathrm{NR}_{2}{ }^{2}\right]_{0}=0.100 \mathrm{~mol} / l\right)$

\begin{tabular}{|c|c|c|c|c|c|}
\hline $\begin{array}{l}\text { トリアルキルゲ } \\
\text { ルミルアミン }\end{array}$ & 溶 媒 & $\begin{array}{l}\text { 温 度 } \\
\text { (C) }\end{array}$ & $\begin{array}{c}k_{2} \\
(l / \mathrm{mol} \cdot \mathrm{sec})\end{array}$ & $\underset{\text { (kcal/ }}{E_{\mathrm{a}}}$ & $\begin{array}{c}\Delta S^{\neq} \\
\text {(cal/ } \\
\text { deg. } \\
\text { mol) }\end{array}$ \\
\hline $\begin{array}{l}\left(\mathrm{CH}_{3}\right)_{3} \mathrm{Ge}- \\
\mathrm{N}\left(\mathrm{C}_{2} \mathrm{H}_{5}\right)_{2}\end{array}$ & $\begin{array}{l}\text { エチレンジ } \\
\text { クロリド }\end{array}$ & $\begin{array}{l}55.0 \\
60.0 \\
65.0\end{array}$ & $\begin{array}{l}(3.14 \pm 0.06) \times 10^{-3} \\
(3.81 \pm 0.04) \times 10^{-3} \\
(4.94 \pm 0.05) \times 10^{-3}\end{array}$ & 11 & -41 \\
\hline 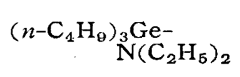 & $\begin{array}{l}\text { エチレンジ } \\
\text { クロリド }\end{array}$ & $\begin{array}{l}55.0 \\
60.0 \\
65.0\end{array}$ & $\begin{array}{l}(4.01 \pm 0.06) \times 10^{-3} \\
(4.58 \pm 0.06) \times 10^{-3} \\
(5.71 \pm 0.05) \times 10^{-3}\end{array}$ & 8 & -41 \\
\hline \multirow[t]{2}{*}{$\left(\mathrm{CH}_{3}\right)_{3} \mathrm{Ge}-\mathrm{N}$} & $\begin{array}{l}\text { エチレン } \\
\text { クロリト }\end{array}$ & $\begin{array}{l}55.0 \\
60.0 \\
65.0\end{array}$ & $\begin{array}{l}(1.9 \pm 0.2) \times 10^{-2} \\
(2.3 \pm 0.1) \times 10^{-2} \\
(3.0 \pm 0.2) \times 10^{-2}\end{array}$ & 11 & -35 \\
\hline & トル & 65.0 & $(1.74 \pm 0.08) \times 10^{-3}$ & - & - \\
\hline
\end{tabular}

ケイ素の場合と同様に開裂はアルキルー酸素で起こっていると結 論しらる。また $N$-トリメチルゲルミルピペリジン,トリーnーブチ ルゲルミルジェチルアミンについて，3.1・1 と同様の測定より二 次式の成立することが観測された。これら三者のゲルミルアミン につき 55,60 および $65^{\circ} \mathrm{C}$ で測定した速度定数および活性化パ ラメータを表 3 に示す。

トリメチルシリルジアルキルアミンに対し $3 \cdot 1 \cdot 1$ で観察された よ5に, トリメチルゲルミルジアルキルアミンの場合でも母体第 2 アミンの $\mathrm{p} K_{\mathrm{a}}$ 值 ${ }^{8}$ から推定して窒素原子の塩基性の大きな $N$ トリメチルゲルミルピペリジンの $65^{\circ} \mathrm{C}$ に括ける $k_{2}$ 值がトリメ チルゲルミルジェチルアミンのそれよりも 6.0 倍大きく，これは 対応寸る両者のトリメチルシリル体で 5.7 倍である (表 1 ) のと よく一致して扣り，反応速度のアミン塩基性に対する依存性はほ ぼ等しいと考只られる。なわち $\beta-P L$ 上の $\beta$ 炭素に対する窒素 原子の求核攻撃がトリアルキルゲルミルジアルキルアミンでも速 度決定段階で重要な役割を演じていることは明らかである。

表 3 から極性の比較的大きなエチレンジクロリド中の $k_{2}$ 值が トルエン中のそれにくらべ約 18 倍大きいことがわかる。この結 果は $3 \cdot 1 \cdot 2 て ゙$ 記したトリメチルシリルジアルキルアミンの場合の 結果と対応しており，反応の遷移状態が双極型の電荷分布をとる ことを支持している。

一方，ゲルマニウム原子上の三つのアルキル基がメチル基から n-ブチル基と変化しても, 反応速度に対しては窒素原子上の置換 ほどの大きな影響が現われないことは興味深い。もしも $\beta$-PLの 開環反応が， $\beta$-PL のいずれかの酸素原子のゲルマニウム原子に 対する配位によって促進される，いわゆる四中心型機構を経て進 行するものならば, 立体効果およびアルキル基の電子供給性感応 効果からも反応性の順序は $\left(\mathrm{CH}_{3}\right)_{3} \mathrm{Ge}->\left(n-\mathrm{C}_{4} \mathrm{H}_{9}\right)_{3} \mathrm{Ge}-$ となるこ とが予想される。しかしながら実測 $k_{2}$ 值は両者の間にそれ程の 差がなく，むしろ上の予想とは逆に 55〜 65으 ではわずかながら $\left(n-\mathrm{C}_{4} \mathrm{H}_{9}\right)_{3} \mathrm{Ge}->\left(\mathrm{CH}_{3}\right)_{3} \mathrm{Ge}$-となり， $\beta-\mathrm{PL}$ の酸素原子のゲルマニ ウム原子に対する配位よりは前述したようにトリアルキルゲルミ ルジアルキルアミンにおける窒素原子の求核攻撃がはるかに重要 であることがわかる。反応性の順序が $\left(n-\mathrm{C}_{4} \mathrm{H}_{9}\right)_{3} \mathrm{Ge}->\left(\mathrm{CH}_{3}\right)_{3} \mathrm{Ge}-$ となることは, $n$-ブチル基の電子供給感応効果がメチル基のそれ より大きく，ゲルマニウム原子を経由し窒素原子に伝達され，そ のため窒素原子の電子密度を增大させたためとして説明できる。 両グルミルアミンの速度定数の差は主としてェンタルピー項に支 配されて批り $\Delta S^{\mp}$ は等しい。

表 3 に示したトリアルキルゲルミル体の活性化エネルギーおよ びェントロピー值はいずれの場合も対応するトリアルキルシリル 
体のそれらにくらべて小さい。さらに重要な点は，表 1 と表 3 の 值を比較して明らかなよ5に, トリメチルゲルミルジアルキルア ミンの方が対応するトリメチルシリルジアルキルアミンにくらべ 数倍ないし十倍も反応性が大きいことである。トリアルキルゲル ミルジアルキルアミンの活性化エネルギー值がトリメチルシリル ジアルキルアミンより低いことはこれと対応している。この大き な反応性の違いがケイ素とゲルマニウムのわずかな電気陰性度の 差 ${ }^{13)}$ に起因すると考えることは困難であり，次式に示したいわゆ る $\mathrm{d}_{\pi}-\mathrm{p}_{\pi}$ 共役効果の寄与 ${ }^{14)}$ (III) がゲルマニウムに比較してஙイ 素の方が大きく，そのため $\mathrm{Si}-\mathrm{N}$ 結合における公素原子上の共有 電子対の電子密度が減少し, トリメチルシリルジアルキルアミン の求核性が低下したためと考える方が妥当であろう。

$$
\left[>\mathrm{M}-\overline{\mathrm{N}}<\leftrightarrow>\mathrm{M}^{-}=\mathrm{N}^{+}<\right]
$$

$$
\text { III }
$$

$\mathrm{Si}-\mathrm{N}$ 結合において $\mathrm{II}$ の寄与の大きなことは， Si-0 結合の異 常な安定性とも対応しており，すでに多くの場合に認められた事 実である ${ }^{15)}$ 。な著者らは $>\mathrm{Si}-\mathrm{N}-\mathrm{Si}<$ の反応性が $>\mathrm{Si}-\mathrm{N}-\mathrm{C}<$ のそれより小さいことを $\mathrm{CS}_{2}$ 扰よび $\mathrm{PhNCO}$ への付加反応につ いて見出した ${ }^{10)}$ が, これも正の構造の寄与とするのが最も妥当で あろ5。

有機ゲルミルアミンの求核性が有機シリルアミンより大きいだ めに反応性が増大したと考光れば，先に記した有機金属アミンの 塩基性の効果とも符合する。

\section{$3 \cdot 3$ 反応様式の検討}

$\beta-P L$ の開裂様式がトリメチルシリルジアルキルアミン5) およ びトリアルキルゲルミル ジアルキルアミン6) でアルキル-酸素開 裂である事実および 3・1 3.2 で記したよ5に窒素原子の求核攻 撃が双極型電荷分布を有する遷移状態を経て進行すると推定され ること，抽よひ $3 \cdot 2$ で述べたよ5に金属原子上のアルキル置換基

13）熊田 誠, 大河原六郎編, “有機ヶイ素化学”, 椇書店(1959) p. 21.

14) U. Wannagat, "Advances in Inorganic and Radiochemistry", vol. 6 (1964) p. 225.

15) 文献 13), p. 26.
は反応速度に二次的な効果を拈よぼすにすぎないことから, 反応 の第一段階は N に示した遷䔟状態を経て $\beta$-PL がアルキル-酸素 開裂を行ない，Vのようなベタイン型の中間体を生成するものと 洘えられる。<smiles>CN(C)[Al](C)C</smiles>

IV

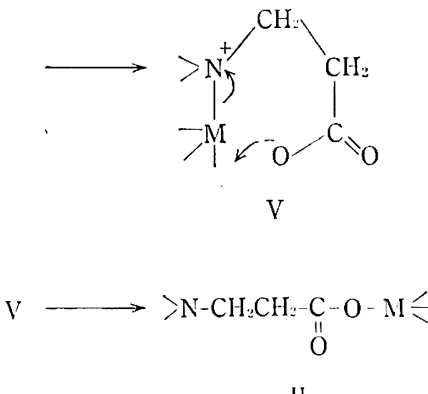

II

Vのベタイン中間体は Gresham ら ${ }^{16)}$ が第三アミンと $\beta-P L$ の 反応でベタインを得ている事実からも裏付けられよ5。

な拈トリメチルスタニルジアルキルアミンに拈いてはケイ素お よびゲルマニウムの場合とはまったく異なり, 式（3）で示した 開裂様式で反応寸る6) ことから $\beta$-PL のカルボニル酸素原子のス ズ原子に対する配位が重要であると予想される。しかしこの反応 は非常にはやく，本報で述べた赤外吸収スペクトルによる測定に よる速度論的研究は不可能であった。

（昭和 41 年 4 月 日本化学会第 19 年会一部講演） 本研究は文部省試験研究費に負うところが大きい。また $\beta$ ○プ ロピオラクトンをいただいたダイセル(株), トリメチルクロルシ ランをいただいた信越化学工業（株）に感謝する。

16) T.L. Gresham, J.E. Jansen, F.M. Shaver, R. A. Bankert, F. T. Fiedorek, J. Am. Chem. Soc., 73, 3168 (1951). 